\title{
Between a Rock and a Hard Place: \\ The T⿱älibān, Afghan Self-Determination, and the Challenges of Transnational Jihadism*
}

\author{
Jan-Peter Hartung
}

London

\begin{abstract}
At the core of this article stands an investigation into a legal response by a Pakistani official of the Tälibān to the claim of the caliphate by IS leader Abu Bakr alBaghdādī. This treatise is understood here as an important position paper of the Tälibān as a whole, reacting to the changing landscape of global Islamic militancy. As such, it was triggered by a number of only loosely connected events: firstly, there is the defection of a faction of the Pakistani Talibān to the IS, resulting in the establishment of its governorate "Khurasan". This coincided, secondly, with the release of documents by the leadership of al-Q $Q \bar{a}$ id $i$ in which it declared its unconditional allegiance to Tālibān leader Mullā Muhammad 'Umar. The third event was the official declaration of Mullā 'Umar's death in July 2015 and the

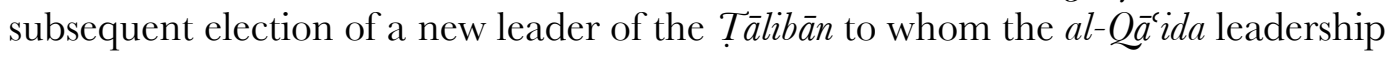
has now transferred its allegiance.

In this article it is shown that the Tälibann, as a movement with only regional aspirations, find themselves trapped in a dispute over global leadership within Muslim militant circles, crystallizing between al-Q $\bar{a} i d a$ and the IS.
\end{abstract}

\section{Keywords}

Islamism, Jihadism, Salafism, Țālibān, al-Qāìida, Islamic State, Caliphate, Mullā 'Umar, Abū Bakr al-Baghdādī 
At the latest since the refusal of the Afghan Tālibān to hand over Usāma ibn Lādin to the US authorities in the immediate aftermath of the attacks on American landmarks on 11 September $2001,{ }^{1}$ and the subsequent military invasion of the Islamic Emirate of Afghanistan by the USA and its allies in what they euphemistically called "Operation Enduring Freedom", the Tăliban have been inseparably linked with transnational Islamic militancy. Consequently, alongside captured

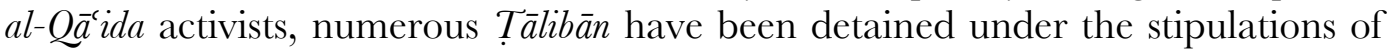
the US Senate Joint Resolution 23 (ratified on 18 September 2001)2 as "illegal enemy combatants" at the Guantánamo Bay Detention Camp in south-eastern Cuba. ${ }^{3}$

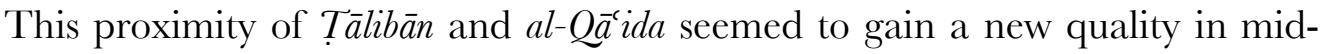
2015 when Ayman al-Zawāhirī (b. 1370/1951), the current amīr of the latter, pledged his unconditional allegiance to the newly elected commander-in-chief of the Taālibān, Mullā Akhtar Manșūr (b. 1383/1963). ${ }^{4}$ However, while Zawāhirī's bay' $a$ had been accepted, the apparent closeness of the two outfits is rather deceptive.

In fact, leading Tälibān detainees, such as the former ambassador of the Islamic Emirate of Afghanistan to Pakistan Mullā 'Abd al-Salām Zàîif (b. 1388/ 1968), have hinted at a less affectionate relationship between the Afghans and the Arab and Central Asian fighters on their soil than public imaginary would have it. ${ }^{5}$ Apart from a shared deep-seated loathing of the "West" as epitomé of successful alternative norms and values, they in fact had little in common. An especially prominent point of difference was the strategic logic of "near enemy" and "far enemy", which informed much of al-Q $Q \bar{a} i d a$ 's agenda, ${ }^{6}$ but wholly contrasted with

* The Romanization of the various relevant languages in non-Latin script for which the WI does not make any clear provision follows the ALA-LC conventions for each respective language. Finally, an " $h$ " struck out (h) indicates aspiration of the preceding consonant.

1) See Abdul Salam Zaeef. My Life with the Taliban, ed. and trans. Alex Strick van Linschoten and Felix Kuehn (London: Hurst / New York: Columbia UP 2010), $145 f$.

2) This document is also known as "Authorization for Use of Military Force Against Terrorists" (AUMF). See www.gpo.gov/fdsys/pkg/PLAW-107publ40/html/PLAW-107publ40. htm (accessed 13 September 2015), section 2 (a).

3) Prominent figures in this regard, who have tried to come to terms with their experiences in written accounts, are erstwhile ambassador Mullā 'Abd al-Salām Zà īf and former journalist 'Abd al-Rah̄īm Muslim Dost (b. 1379/1960). See Mullā 'Abd al-Salām ZZa īf. Da Guvāntānāmo anżūr (n.p.: no publisher 1385sh); 'Abd al-Rahīm Muslim Dost and Badr al-Zamān Badr. Da Guvāntānāmo mātezolānah: da 1/9/1422h spożћmiz nah tar 9/2/1426h spożћmīz (Quetta: Khilāfat khpandviyah tolānah 1427h).

4) See Ayman al-Ẓawāhirī. 'al-Bay'a tanẓ̄m al-Qāioida ma'a Ṭālibān imārat Afghānistān al-islāmiyya amīr al-mu'minīn al-mullā Akhtar Muhammad Manșūr' (Mu'assasat al-sahāb 13 August 2015), URL: https://pietervanostaeyen.wordpress.com/2015/08/13/dr-ayman-az-zawahiri-pled ging-baya-to-mulla-akhtar-muhammad-ma nsur/ (accessed 31 August 205).

5) See Zaeef, My Life, $135 f$ and 157-9.

6) The notion of "adūw gharīb" and "adūw ba '̄id" seems to have appeared for the first time explicitly in the early 1980s, as for example in Muhammad 'Abd al-Salām Faraj. al-fihäd: al-farìda al-ghä’iba (n.p. 1981), 15f. Compatriots of Faraj, like Ayman al-Zawāhirī, have later taken this

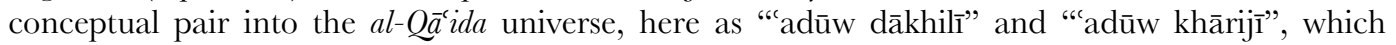


the Tälibān's focus that remained solely on Afghanistan. In this, the Tälibān appeared as true heirs to the war of liberation from Soviet occupation in the 1980s, and the subsequent civil war in Afghanistan that lasted until their final seizure of power in 1994. However, the persistent existence of al-Q $\bar{a}^{\prime} i d a$ representatives, including its leadership, in Tälibān-controlled areas in the Afghanistan-Pakistan frontier region, begs nonetheless for a directed probe into the nature of the ostensibly uneasy relationship between the Tälibān, in several of its manifestations over time, with an equally amorphous $a l-Q \bar{a}^{c} i d a$.

A guiding question in this investigation is whether the emergence of new powerful forces among Muslim militants, such as prominently the Dawla islämiyya (IS), ${ }^{7}$ and the resulting contestations over leadership of a global jihädi front has had an impact on this bilateral affiliation and, if so, whether such a development was indeed mutual, as suggested by Zawāhirīs bay'a to Akhtar Manșūr and its acceptance. Conversely, I argue that, in the conflict over the supreme command in the transnational Jihadist circles, the Tälibān became caught between the pull of the $I S$ and the appropriation by al-Q $\bar{a} i d a$, while they seek to assert their regionally confined self-determination with increasingly new argumentative tools. This inquiry therefore begins with observations of the more recent developments in the landscape of Islamic militancy, which in a next step are juxtaposed with the historical development of the Tāliban-al-Q $Q \bar{a} i d a$ relationship. This will be followed by shedding some light on the recent developments from a Tâlibān perspective, before a preliminary conclusion is finally drawn.

\section{A New Momentum}

Zawāhirī’s bay'a to Akhtar Manșūr is the current culmination point of a fierce and long-lasting contestation of leadership within the militant Salafist spectrum. In this dispute, al-Baghdādī was positioned against "the Commander of the Faithful" Mullā Muhammad 'Umar, the enigmatic leader of the Afghan Tälibān and

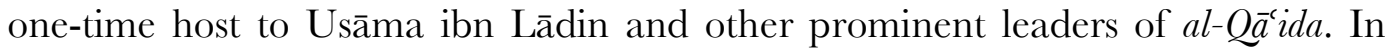
justifying the leadership of Mullā Umar, these al-Q $Q \bar{a}^{c} i d a$ commanders refer back to 4 April 1996, when Mullā 'Umar donned the cloak that once allegedly had belonged to the Prophet and since the eighteenth century has been kept in the $D a$ khirqah sharif ziyarat in Qandahar, and the assembled crowd, which contained numerous religious dignitaries, cheered him as "amīr al-mu'minīn". Mullā 'Umar had

adds an interesting momentum to this conceptual binary. See Ayman al-Zawāhirī. al-Fursān tahta rāyat al-nabì, 2 vols. (n.p.: Mu'assasat al-sahāāb $\left.{ }^{2} 1431 / 2010\right)$, I: 9-14 and 63. From there, the notion of "near/far enemy" has apparently become a fast-selling item in academic circles, as indicated by works such as Guido Steinberg. Der nahe und der ferne Feind: Die Netzwerke der islamistischen Terrorismus (Munich: Beck 2005) and Fawaz A. Gerges. The Far Enemy: Why Fihad went Global (Cambridge et al.: CUP 2005).

7) The outfit is in fact known by various names, most prominently al-Dawla al-islāmiyya fi'l-'Irāq wa'l-Shām $(D \bar{A} ' I S H)$ or its direct English renderings ISIS or ISIL. The emphasis here however shall be on its ideological aspiration, which in fact is global in scope, rather than giving credit to its current geo-political existence in a defined region, therefore the de-territorialized label "IS" is adopted. 
thus effectively received a caliphal epithet from the hands of his community. ${ }^{8}$ Whether he actually intended this, or whether it was rather a spontaneous expression of religious excitement by the crowd, Mulla 'Umar accepted the title and henceforth signed all his official correspondence and public announcements as "Commander of the Faithful", alongside "Custodian of Islam" (khädim al-isläm). ${ }^{9}$

Meanwhile, the rejection of Mullā 'Umar as legitimate caliph by the $I S$ cadres was not without basis: after all, the Afghan commander has been physically absent from the community he claimed to lead for over a decade, having been forced to go underground by the successes of the US-led military alliance in Afghanistan since 2001 and the promise of a healthy reward of up to US $\$ 10$ million by the US authorities for information regarding 'Umar's whereabouts. ${ }^{10}$ An example of such dissent from groups with T⿱älibān affiliations is the Özbekiston Islomiy Harakati (IMU), who have - ostensibly on these grounds - increasingly withdrawn from the Tâlibān and eventually, in September 2014, declared their allegiance to al-Baghdādī. ${ }^{11}$

Around that time, IMU cadre Asadulloh Urganchiy (b. 1391/1971), who is allegedly based in the Fāryāb province of north-western Afghanistan, ${ }^{12}$ claimed that the maintenance of allegiance to Mullā 'Umar would, due to the latter's physical absence, be in contradiction to the $\operatorname{sharit}^{-1} a$, and a transfer of the pledge onto al-Baghdādī was therefore entirely justified, even indispensable. A few months earlier, however, in May 2014, the celebrated Jihadist theorist Abū

8) See Ahmed Rashid. Taliban: The Power of Militant Islam in Afghanistan and Beyond, revised edition (London: I.B. Tauris 2008), 42. Research on the origins of the title "amī al-mu'mininn" appears rather scarce so far. See Patricia Crone and Martin Hinds. God's Caliph: Religious Authority in the First Centuries of Islam (Cambridge et al.: CUP 1986), 11 and 16; Madelung, Succession, 49. On the historical significance of the cloak at Qandahar for the political ethnogenesis of the Afghan nation, see Louis Dupree. Afghanistan (Princeton, NJ: PUP 1973), 339; and Asta Olesen. Islam and Politics in Afghanistan (Richmond, Surrey: Curzon 1995), 159.

9) See Muhammad Riẓā Hāāj Bābāȳi (ed.). Qavān̄̄n-i Mullā 'Umar: majmū'ah-yi qavān̄̄n va àyñn'nāmah'hā-yi TTălibān dar Afghānistān (Tehran: Nigāh-i amrūz 1382sh), passim. Interestingly, though, this nomenclature has been tacitly taken over by Mullā 'Umar's successor as amīr of the Tâalibān, as the latest address on occasion of 'Īd al-aḍá 1436 (22 September 2015) indicates. See 'Da nekmarghah loye-akhtar da rā-rasedo pah munāsibat da amīr al-mu'minīn Mullā Akhtar Muḥammad Manșūr — ḥafiẓahu allāh — payghām', URL: http://alemaral. org/?p=28812 (accessed 5 October 2015).

10) See www.rewardsforjustice.net/english/mullah_omar.html. The "Rewards for Justice" program of the US State Department was launched in 1984 as part of the 1984 Act to Combat International Terrorism, Public Law 98-533.

11) See 'Halif Abu Bakr Baghdodiyga özbekistonliklar dan bay'at.' Shom TV (http://hilofatnews. com/Video_v6902. html). The video had been released around 13 July 2014, but is not accessible anymore because of violation of YouTube Terms of Service. Whether or not this bay' $a$ had been accepted by al-Baghdādī is still a matter of dispute.

12) On Urganchiy, no further biographical information could be found. Many of his writings, however, appear prominently on the IMU website www.furqon.co [sic], hosted by a server in the Zlín region of the Czech Republic (accessed 2 July 2015). It is interesting to note that, according to a statement by official Tâalibān spokesman, dated 25 August 2015, no Uzbek militia was operating from Afghan territories. See 'Da islāmī imārat vayānd Zảāịallāh Mujāhid yaw-laṛramahmū suvālūnū tah żavābūnah vīlī, URL: http://alemaral.org/?p=25669 (accessed 31 August 2015). 
Muhammad al-Maqdisī (b. 1378/1959) ${ }^{13}$ issued a declaration on behalf of the militant Jabhat al-Nusra li-Ahl al-Shām, the Levantine wing of al-Q $\bar{a}^{c} i d a$, in which he reacted strongly against al-Baghdādî̀'s attempt about a month earlier to extend his control over al-Nușra. ${ }^{14}$ Though not ostensibly taking up the cudgel for Mullā 'Umar, al-Maqdisī indirectly furthered his cause when he asked:

Will this Caliphate be a sanctuary for every oppressed one and refuge for every Muslim? Or will this creation take up a sword against those who oppose it from among the Muslims, and cut away with it all the Emirates that came before their declared state, and nullify all the groups that fight jihād in the Path of God in the different battlefields before them? ${ }^{15}$

Clearly, al-Maqdisī wanted the $I S$ to acknowledge their own pedigree. They had

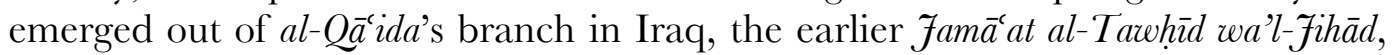
which was initially led by Abū Muṣ́ab al-Zarqāwī (killed 1427/2006), but around 2010 taken over by Abū Bakr al-Baghdādī. The latter, however, severed all ties with his former commanders, when, on 17 April 2014, the $I S$ spokesman Abū Muhammad al-'Adnānī "the Syrian" (b. 1397/1977)16 declared in an official audio message their rejection of al-Q $Q \bar{a} i d a$ command, citing the latter's adoption of a new and disputable "method" (manhaj) - a core term of the Salafist discourse 17 - as ultima ratio for this defection. ${ }^{18}$ Zawāhirī, as the current amīr of al-Q $\bar{a}$ c $i d a$, reacted almost instantly with an audio message, strongly pleading to not sow dissent among the mujāhidün, but rather to bow to "party discipline" and relocate back to Iraq, leaving Syria in the hands of Jabhat al-Nusra. ${ }^{19}$ The futility of this and

13) The standard work on him so far remains Joas Wagemakers. A Quietist Salafi: The Ideology and Influence of Abu Muhammad al-Maqdisi (Cambridge et al.: CUP 2012).

14) See Abū Muhammad al-Maqdisī, F̄̌ bayān hāl "al-Dawla al-islāmiyya fi'l-'Irāq wa'l-Shām" wa'l-mawqif al-wäjïb tujāhahā (Minbar al-tawhīd wa'l-jihād 19 Rajab 1435/19 May 2014). URL: http://justpaste.it/fm4t (accessed 20 August 2015).

15) Ibid.

16) On 'Adnānī's biographical background, see the short eulogizing essay by IS ideologue Turkī ibn Mubārak al-Bin'alī, nom-de-guerre "Abū Humām Bakr ibn 'Abd al-'Azīz al-Atharī" (b. 1405/1984), al-Lafz al-sānī fì tarjamat al-'Adnānī, "manjuñ̄q al-dawla al-islämiyya” (JustPaste.it 27 Rajab 1435/26 May 2014), URL: http://justpaste.it/g7qa (accessed 5 October 2015).

17) Manhaj constitutes the outward aspect of the Salafist worldview, the inward one being "creed" ('aqìda). Most Salafist authors maintain that, while the 'aqìda remains unchanged, the manhaj, referring to a legal methodology as well as to the actions derived from it, is subject to changes depending on an evaluation of the temporally and spatially variant context (fiqh al-wāqi ).

On the role of manhaj in Salafist discourse generally, see Justyna Nedza. "«Salafismus» Überlegungen zur Schärfung einer Analysekategorie.' Salafismus: Auf der Suche nach dem wahren Islam, ed. Behnam T. Said and Hazim Fouad (Freiburg i.B. et al.: Herder 2014), 80-105, here 88-90.

18) The statement was titled "This was never our Method, and never will be" (mā kāna manhajunā wa-lan yakūnu) (Mu'assasat al-furqān li'l-intāj al-i'lāmī 17 April 2014). URL: https://isdarat.tv/2467; for an English translation, see https://pietervanostaeyen.wordpress.com/2014/04/18/message-by -isis-shaykh-abu-muham mad-al-adnani-as-shami/ (both accessed 19 August 2015).

19) See al-Ẓawāhirī, 'Shahādat li-ḥaqana dimā’ al-mujāhidīn bi’l-Shām' (Múassasat al-sahāb 3 May 2014), URL: https://archive.org/details/sheham-history2 (accessed 20 August 2015). Zawāhirī received further reinforcement of his viewpoint by Abū Muhammad al-Maqdisī in late May 2014 (see $F \bar{\imath}$ bayān $h \bar{a} l)$. The original postings are no longer retrievable because of the shut-down of the 
related attempts to curb the influence of the $I S$ over militant Islamists worldwide became an undeniable fact when, on 11 May, al-'Adnānī released a new official statement, this time directly addressed to al-Zawāhirī, in which he rejected all the arguments of al-Zawāhirī and his associates for the reestablishment of unity among militant Islamist under the umbrella of al-Q $Q \bar{a} i d a$, stressing that 'the [Islamic] State is neither a branch nor a subordinate to al-Q $\bar{a}$ c $i d a$, nor was it at any time'. ${ }^{20}$ An important point is made only in passing, when al-'Adnānī claims that al-Zawāhirī and his closest associates, still in hiding somewhere in the Tribal Areas of Pakistan's Khyber-Pakhtunkhwa Province, 'are today soldiers under the authority [tahta sulțann] of Mullā 'Umar'21, allegiance to whom cannot rightfully pledged by an emirate or state, since he represents only an organization (tanzim).

Such dismissive words against Mullā 'Umar resonate quite vividly with an alleged later statement by Abū Bakr al-Baghdādī himself, in which he declared the Afghan 'an idiot [ma'tūh] and ignorant warlord [amīr harb jāhil]' who 'does not deserve any spiritual or political credibility [ayy mișdāqiyya rūhiyya aw siyāsiyya]'.22

Meanwhile, on 9 May 2015 representatives of the Tâlibān - here its Pakistani wing (TTP) - finally entered the floor in this dispute over leadership. A Pashtun militant writing under the name "Abū 'Us_mān Sālārzạy" published an interesting document on the official website of the TTP. In this document, published simultaneously in Arabic and Pashto, Sālārzạy claims to present the official statement of the Supreme Council of the Pakistani Țälibān regarding the claims to the caliphate put forth by Abū Bakr al-Baghdādī and his supporters of the IS. In a lengthy exposition, the author presents his elaboration of twenty-two arguments 'in the light of the sublime oral traditions, the pearls of the texts from the Book and the Sunna, and the consensus of the community'23 against these claims.

Two dominant lines of conflict are visible here. The first one consists of a dispute over rightful leadership over militant Islamists worldwide between al-Q̄a $i d a$ and its adolescent, rebellious spin-off the IS. At the surface of this

homepages of al-Maqdis̄i and associates, such as Abū Qatāda al-Filasțīnī (b. 1379/1960), some time in spring 2015. Whether or not this is related to Maqdisīs arrest in October 2014 by the Jordanian authorities on the suspicion of fomenting terrorism on the internet needs to remain open for now.

20) Abū Muḥammad al-'Adnān̄̄ al-Shāmī. 'Udhran, amīr al-qāi ida' (Mu'assasat al-furqān li’l-intāj al-i`lāmī 11 May 2014). URL: https://isdarat.tv/2463 (accessed 19 August 2015), mins. 12’20'”$25^{\prime \prime}$.

21) Ibid., mins. 12'32'-45"'.

22) Anonymous. 'al-Baghdādī: al-Mullā 'Umar ... "ma'tūh".' al-Wațan al-'arabī 30 January 2015. URL: www.alwatanalarabi.com/article/61111/\%D8\%A7\%D9\%84\%D8\%A8\%D8\%BA $\%$ D8 $\%$ $\mathrm{AF} \% \mathrm{D} 8 \% \mathrm{~A} 7 \% \mathrm{D} 8 \% \mathrm{AF} \% \mathrm{D} 9 \% 8 \mathrm{~A} \% \mathrm{D} 8 \% \mathrm{~A} 7 \% \mathrm{D} 9 \% 84 \% \mathrm{D} 9 \% 85 \% \mathrm{D} 9 \% 84 \% \mathrm{D} 8 \% \mathrm{~A} 7 \% \mathrm{D} 8 \% \mathrm{~B} 9 \mathrm{D} 9$ $\% 85 \% \mathrm{D} 8 \% \mathrm{~B} 1 \% \mathrm{D} 9 \% 85 \%$ D8\%B9\%D8\%AA $\% \mathrm{D} 9 \% 8$ 8\%D9\%87 (accessed 9 July 2015). The original statement of al-Baghdādī, allegedly issued on 29 January 2015, could not be located and its veracity remains therefore to be proven.

23) al-Sālārza'̄̄, Abū 'Uthmān. Mawqî harakat Ṭālibān al-bākistāniyya 'an khilāfat al-Shaykh al-Baghdād̄̄ - hafizahu allāh — al-maz'ūma (n.p.: Idārah 'Umar barā-yi nashr va ishā'at 1436/2015). URL.: https://umarmedia.files.wordpress.com/2015/05/d985d988d982d981d8add8b1d983d8a9-d8b7d 8a7d984d8a8d8a7d986-d8a7d984d88d8a7d983d8b3d8aad8a7d986d98ad8a9-click-here-to-downl oad1.pdf (accessed 2 July 2015), 6. 
argument lie ostensibly different conceptions of the method (manhaj) of $j i h \bar{a} d,{ }^{24}$ but a more specific undercurrent is the negotiation of authority following the assassination of Usāma ibn Lādin, whose leadership appears to have been undisputed by today's $I S$ renegades. ${ }^{25}$ It may not be surprising to see the conflicting parties looking back to the early Islamic tradition for guidance. After all, all the people involved here aspire to emulate what they consider to be the ultimate yardstick for perfection, that is, the practice of the salaf sâlith. This retrospection reveals a precedent for dealing with the death of the community leader: with the demise of a caliph, all bets were off and - ideally - the umma would have to decide over the succession; ${ }^{26}$ hence the assumption of the leadership of al-Q $Q \bar{a}^{-} i d a$ by al-Zawāhirī almost instantly after the assassination of Ibn Lādin ${ }^{27}$ could legitimately be challenged by former cadres of the organization. In fact, all the arguments presented by either side in this polemical dispute revolve around the question of whether or not each contender for leadership conforms to the appropriate manhaj, which appears as a standard debate in Salafist circles of whatever provenance. ${ }^{28}$

With the Tälibān, however, a second line of conflict emerges that informs a different rhetoric in arguing for or against a given claimant for leadership. Transnational Jihadist leadership has never been an aspiration of the Tālibān, who, throughout their existence, have hardly ever aspired to extend their dominion beyond Afghanistan and the Pashtun region of western Pakistan. As such, their direct interactions with various militant actors from the Middle East and other regions of the Muslim world were based rather on an interpretation of the tribal

24) See al-Shāmī. 'Udhran, mins. 27'30' $-29^{\prime} 44^{\prime \prime}$, here 27'30'-39'" 'The bottom line is that the dispute between the $I S$ and the leadership of $a l-Q \bar{a}^{c} i d a$ is a dispute of methodologies [khiläf manhajizy] $\ldots$ and it is not about who pledged allegiance to whom or who references whom [bay'atu man li-man wa-marja'iyyatu man li-man].'

25) See ibid., mins. 16 $00^{\prime \prime}-16^{\prime \prime}$ : And here we are extending our hands to you again, to be the worthy successor to the best of the elders [khayra khalafin li-khayri salaf]; for the shaykh Usāma [ibn Lādin] united the mujāhidūn upon one word, whereas you disunited them, split them and dispersed them in total dispersion [farraqtahā wa-shaqaqtahā wa-mazzaqtahā kulla mumazzaq].'

26) This, of course, has historically hardly been the case. See, for example, M. J. Kister. 'Notes on an Account of the Shura appointed by 'Umar b. al-Khattab.' Journal of Semitic Studies 9:2 (1964), 320-6; and Wilferd Madelung. The Succession to Muhammad: A Study of the Early Caliphate (Cambridge: CUP 1997).

27) The succession to Ibn Lādin was only officially announced more than a month after his assassination, giving rise to speculations about internal leadership disputes. For the text of the announcement, see https://archive.org/details/lbikfurypxmx (accessed 19 August 2015).

28) For example, see Abū Qatāda 'Umar ibn Maḥmūd al-Filasț̄n̄ī. Risāla ilá ahl al-jïhād wa-muhibbih (n.p. 1435/2014), 1: 'Those that blame the command of jihäd and leaders like the Doctor [ka'l-hakim] al-Zawāhirī, or those that claim that he has changed [his manhaj] are those who play with words. This is because they have no experience regarding the path of $j i h \bar{a} d$, nor do they understand the belief of the people of jihha $d$, their words or method [lā uslübahum]. It is strange that it is claimed that the Doctor - may God protect him — sees matter differently to Abū 'Abdallāh [Usāma] ibn Lādin.'

On manhaj in the thought of al-Maqdisī, which coincides with the respective views of Abū Qatāda, see Wagemakers, Quietist Salafi, 75-95. 
customs of unconditional hospitality (Pashto: melmastiya, or melmah palānah) and, inseparably linked to it, of sanctuary (Pashto: panāh, or nanawätay), ${ }^{29}$ rather than on a common agenda. ${ }^{30}$ Instead, what riled them was the explicit contestation of Tälibān leadership by the $I S$, through their establishing the caliphate of al-Baghdādī, and their attempt in doing so to open up Taalibān cadres to a more trans-regional agenda.

\section{The Intricate Relationship of the Tālibān and al-Q̄̄ंida: A Brief History}

In order to better understand the dynamics between the various actors under review, a brief historical excursion into the origins and development of the relationship between the Täliban with what would eventually become known as $a l-Q \bar{a}^{c} i d a$ is necessary. In this regard, it is important to note that the relationship between Deobandī scholarship in the Frontier region - the intellectual context from which the Tälibān emerged - and the Arab Muslim world was initially rather lose. While the collected correspondence of the principals of the Fämi ah haqqaniyyah at Akorah Khattak contains a whole volume of exchanges with the wider Muslim world, the exchange with Arab dignitaries remained formal and rather confined. Moreover, nothing in these exchanges foreshadowed a stronger leaning towards those Muslim thinkers that would eventually contribute to the

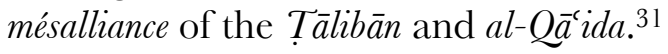

When the founding principal of the Haqqāniyyah, Mawlānā 'Abd al-Haqq (d. 1409/1988), went on hajj for the first time in 1964, he came into direct contact with leading Muslim Brethren from Egypt and Syria, but the account of this meeting in a Mecca hotel suggests that he was largely oblivious of the who-is-who of Arab Islamism. ${ }^{32}$ This indifference seems to have continued in the correspondence of his son and successor as principal of the Haqqāniyyah, Mawlānā Samī‘

29) On these categories, considered to be major constituents of the somewhat idealized Pashtun ethical code — pashtūnwā̄̄ —, see Willi Steul. Paschtunwali: Ein Ehrenkodex und seiner rechtliche Relevanz (Wiesbaden: Steiner 1981); and Bernt Glatzer. 'Zum Pashtunwali als ethnisches Selbstportrait.' Subjekte und Systeme: Soziologische und anthropologische Annäherungen. Festschrift für Christian Sigrist zum 65. Geburtstag, ed. Günter Best and Reinhart Kößler (Frankfurt a.M.: IKO-Verlag 2000), 93-102.

30) See Andreas Rieck. 'Afghanistan's Taliban: An Islamic Revolution of the Pashtun.' Orient 38:1 (1997), 121-42; Vahid Brown and Don Rassler. Fountainhead of Jihad: The Haqqani Nexus, 1973-2012 (London: Hurst / New York: OUP 2013), 105-7. Pakistani columnist Farhat Taj Andersen, however, challenges this narrative on the basis of around 2,000 interviews conducted in the FATA of Pakistan in 2008 and 2009, as well as her own normatively grounded cultural imaginary. See Farhat Taj. Taliban and Anti-Taliban (Newcastle: Cambridge Scholars 2011), 1-4 and 8-11.

31) See Samī` al-Haqq, Mashāhir, VI. Among the prominent Arab correspondents are heads of state and ministers of Saudi Arabia, Egypt and Libya, as well as leading officials in religious affairs in these countries, such as the Grand mufti of Saudi Arabia and the Shaykh al-Azhar.

32) This is vividly shown by the fact that 'Abd al-Haqq (and his son Samī' al-Haqq as editor of his correspondence) seems to have confused the prominent Muslim Brother Sa īd Ramaḍan (d. 1416/1995), editor of the periodical al-Muslimūn and father of prominent public figure Tariq Ramadan (b. 1962), with the Syrian traditionist Muḥammad Sa īd Ramaḍān al-Būṭi (killed 1434/2013). See ibid., I: 254, esp. fn. 1. 
al-Haqq (b. 1356/1937): the only few significant contacts for the development of the matters under review here appear to have been with the leading Saudi Arabian Sahwō scholar Safar al-Hawālī (b. 1375/1955), the Yemenite radical thinker 'Abd al-Majīd al-Zindānī (b. 1360/1942) and the Sudanese Islamist leader Hasan al-Turābī (b. 1351/1932). ${ }^{33}$ These contacts, however, date predominantly

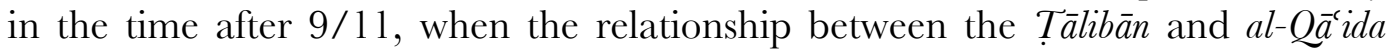
had long since been established. Even the contents of the communication do not really touch upon issues that would suggest a greater participation of the Deobandī scholars of Akorah Khațak and the Tälibān in more global conceptions of Islamic activism.

Of greater significance in this regard seems to be the awareness of organized religious developments in the former Central Asian Soviet Republics from around the early 1990s: in December 1991, Samī al-Haqq offered free tuition at the Haqqāniyyah to 1,000 students from Uzbekistan, some of whom would a few years later be killed in concerted combative action in Afghanistan and Uzbekistan alike. ${ }^{34}$ Equally, almost immediately after its foundation, the Haqqaniyyah established official contact with the Hizbi Nahzati Islomï Tojikiston (NIT), then led by the Islamist Sajid Abdullohi Nurij (d. 1427/2006) who openly advocated the transformation of Tajikistan into an Islamic state. ${ }^{35}$ Contacts were also established with the secessionist Chechens around Yandarbîn Abdûl-Muslimân kânt Zelîmxa (Russ.: Zelimxan Abdulmuslimovič Yandarbiev; assassinated 1424/2004), onetime president of the Chechen Republic of Ichkeria that was formally proclaimed in November 1991. In fact, Yandarbîn's stay at Akoṛah Khațtak in January 2000 provided the framework for the establishment of formal - though rather short-lived $^{36}$ - diplomatic relations between Chechen Republic of Ichkeria and the Islamic Emirate of Afghanistan, a bond that would also unite the various international irregular combatants fighting against the repeated Russian occupation and their counterparts in the Afghanistan-Pakistan borderlands. Figures like Saudi-born Thāmir Șālị̣ 'Abdallāh, better known by his nom-de-guerre "Ibn alKhaț̣āb" (killed 1423/2002), played a crucial role here: having had his baptism of fire between 1988 and 1995 in Afghanistan and Tajikistan, ${ }^{37}$ he moved on to Chechnya to deploy his Islamic International Brigade (IIB; known by an array of different names) there. It was during his training in the Jalalabad camp in Afghani-

\footnotetext{
33) See ibid., VI: 168-71 (al-Turābī), 192-201 (al-Ḥawālī) and 216-22 (al-Zindānī).

34) See ibid., VI: $346 f$ and 351.

35) See ibid., VI: 351-6: the correspondence with Nurij spans from the year 1994 to 2000.

36) With the collapse of Tälibān rule in Afghanistan in late 2001, the successor of Yandarbîn as president of the Chechen Republic of Ichkeria, Masxadan Ali klânt Aslan (assassinated 1426/ 2005), decided to renounce the alliance with the Tālibān, claiming that Yandarbîn's quest for diplomatic recognition of the Chechen Republic from the Tălibān had not at all been authorized. See Ilyas Akhmadov and Miriam Lanskoy. The Chechen Struggle: Independence Won and Lost, London: Palgrave Macmillan 2010), 184f.

37) See Muhammad al-'Ubaydi. Khattab (Westpoint, NY: Combating Terrorism Center 2015), 915.
} 
stan that he also established a personal acquaintance with Usāma ibn Lādin who at that time was regarded as the 'head of the Arab gangs [al-fariq al-'arabi] there' 38 .

What can be deduced from the story so far is that the cognitive map of the Deobandī scholars in the Frontier region from whom the Tälibān would eventually hail was clearly focused on their own region which comprised Muslim Central Asia as well as the Indian subcontinent; the Arabic-speaking Middle East, in turn, was of a more general religious significance to them, but interest in and awareness of actual developments there were ostensibly limited. While Arab volunteers in the resistance against the Soviet occupation of Afghanistan were generally welcome, it was expected that they would subordinate themselves to the local fighters. Usāma ibn Lādin himself is a case in point here: while establishing himself as leading figure among the Arab volunteers, his expertise in guerrilla warfare was clearly limited, as his participation in the disastrous attack on Jalalabad airport in March 1989 had vividly illustrated, ${ }^{39}$ and he would subsequently submit himself to the military and also spiritual authority of the "Amīr al-mujahidīn" Muhammad Yūnus Khāliș (d. 1427/2006), commander of a major offshoot of the Gulbuddin Hikmatyār's Hizb-i islāmē and, moreover, a one-time student of Mawlānā 'Abd al-Haqq of Akorah Khattak. ${ }^{40}$

While Bell cautions against jumping to conclusions here - stressing that Khāliṣ's education had already been completed well before Partition and, thus, the establishment of the Haqqäniyyah - there exists sufficient evidence of the continued relationship between the leadership of the institution and the man whom Usāma ibn Lādin allegedly would call his "Father Shaykh" (al-shaykh al-walīd). ${ }^{41}$ In fact, Khālis served well as a charismatic link between the Haqqāniyyah and aspiring mujāhidūn among its students; in this regard a number of recruitment-events have been held in Akorah Khațak, with Khāliș in attention. ${ }^{42}$ In return, Sam̄̄ al-Haqq kept the links between the institution and its fighting alumni alive when, in his capacity as a secretary general of the Fam'iyyat al-'ulam $\bar{a}^{\prime}-i$ istam (JUI), he visited his former students at Khāliṣ's own encampment, called "Najm al-Jihād", a little south of Jalalabad. ${ }^{43}$ It may have been during such a visit that the scholarpolitician from Pakistan became personally acquainted with Usāma ibn Lādin

\footnotetext{
38) Muștafá Hāmid. Șal̄̄b fì samā’ Qandahār: qișsat al-mujāhidīn al-'arab fì Afghānistān min dukhūl al-awrwal ilá al-khurūj al-akhīr (n.p. n.d.), 26.

39) See ibid., 26-31.

40) See Kevin Bell. Usama bin Ladin's "Father Sheikh": Yunus Khalis and the Return of al-Qa'ida's Leadership to Afghanistan (Westpoint, NY: Combating Terrorism Center 2013), of and 27-9.

41) See the comparatively intense correspondence between Samī` al-Haqq and Khāliṣ between 1979 and 2006 in Samī al-Haqq, Mashähir, VII: 47-59. Here, the seminary at Akorah Khațak is labelled as Khāliș’s "alma mater" (mādar-i 'ilmâ), while the latter addresses Samī al-Haqq as "our shaykh and teacher" (shaykhunā wa-ustādhunā).

42) See ibid., 57.

43) See ibid., 58f.
} 
who ostensibly spent some time there in the mid-1990s after his forced expulsion from the Sudan. ${ }^{44}$

Bell does not give much credit to the appellation "Father Shaykh", arguing that it would only complement the already established and widely used Pashto epithet "Khāliṣ bābā", but carries little additional meaning beyond this. ${ }^{45}$ While one may consent that to consider Khāliṣ a substitute-father for Ibn Lādin, whose real father had died when Usāma was only ten years old, is fairly far-fetched and of little analytical value, an alternative reading of this appellation is certainly relevant. This is to note that the use of an established honorific for the Afghan facilitator indicates Ibn Lādin's at least feigned submission to the existing hierarchies among the Afghan mujähidin at that point. In fact, this would be the expected behaviour of someone considered a guest and protégé in an environment that is clearly shaped by strong traditional tribal values which, in this environment, are not negotiable. Especially in situations of fragile personal circumstances, as was probably the case immediately after Ibn Lādin's expulsion from the Sudan, such subordination carries a strong pragmatic attitude. That it was not an indication of affection between the Arab and his Afghan hosts became finally clear when, a few years on and then as a guest of Mullā Muhammad 'Umar, Ibn Lādin began to conduct arbitrary activities which seriously strained the relationship with his host. ${ }^{46}$ The shifty attitude

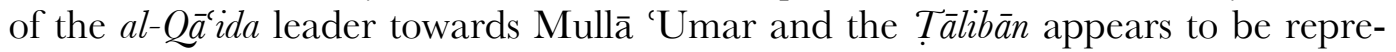
sentative of that of many other non-Afghan Muslim militants who were active in the many conveniently difficult-to-navigate areas of Afghanistan during the time of the Islamic Emirate and beyond.

For most of the newcomers from the Arab world in the late 1990s, what had started as the fight of the Afghan mujāhidūn was not theirs anymore. Hence, their relationship with their Afghan counterparts went only so far as to ensure the un-

44) Bell, Father Shaikh, 31 n. 153, lists an abundance of references to sustain his claim on the same page that 'we can state with some confidence that Khalis hosted the al-Qa ida leader at the housing development near Jalalabad known as Najm al-Jihad.' The references here, however, appear to be exclusively to secondary materials, which appear hardly sufficient to establish the stated confidence in this claim. Also the Pashto references, predominantly Khālis bābā qadam pah qadam (n.p.: Da khaparvalo żāy sargand naday 1390/2012) by writer and poet 'Abd al-Kabīr "Talāy" must be considered secondary ones, and do therefore not really alter this assessment.

That Ibn Lādin and Samī al-Haqq must have established contact at some point and have shared at least some fundamental views is indicated by the fact that the former contributed a special address to a special issue of the Haqqāniyyah in-house journal «al-Haqq» almost immediately after 9/11. See Usāma ibn Lādin. 'Idārah.' al-Haqq 36: 11-12 / 37: 1-2 (2001): ishā'at-i khuṣūsī: ikīsvìn șadì ke chelinjiz awr 'ālam-i istām, 11-5 (trans. n.n.).

45) See Bell, Father Sheikh, 34f. Again, it seems that Bell lacks the required source-critical approach of the good historian, as he rates the various Pashto works on Khāliṣ almost as indicative as a primary text. In fact, most of the works he refers to on p. 3, n. 13 are hagiographical in nature, and to investigate in the motivation of the respective authors would therefore be a prerequisite for a better evaluation of the veracity of these texts.

46) See, e.g., Brown and Rassler, Fountainhead, 105-7. The personal relationship of Mullā 'Umar and Usāma ibn Lādin was ostensibly strengthened by the uncorroborated claim that each one had married into the other's family. 
hindered existence of their increasingly nationally segregated training camps, ${ }^{47}$ their attitude towards their Afghan hosts mainly one of peaceful coexistence and non-interference. Besides this pragmatic arrangement, there is ample evidence that the general attitude of the Arabs towards the Afghans, be they mujāhidūn or just the local population at large, was one of contempt for their perceived backwardness. ${ }^{48}$ For the leadership of $a l-Q \bar{a}^{c} i d a$, however, the relation with the Tāliban appears to have been much more complex, especially after the beginning of US-American attacks on Afghanistan in retaliation for the al-Q $\bar{a}^{c} i d a$-engineered attacks on American targets on 11 September 2001, an attack that was very much in line with the infamous fatwá from 23 February 1998 in which Ibn Lādin declared such action as individual duty of each capable Muslim (fard ' ayn). ${ }^{49}$ With this and similar declarations $a l-Q \bar{a}^{c} i d a$ established non-regional targets as prime concern of the international Muslim volunteers on Afghan soil, which would very much impair the locally confined agenda of the Tâlibān during the Islamic Emirate of Afghanistan. As it was precisely this line of thinking that was responsible for the eventual invasion of Afghanistan by US-American and allied troops in October 2001, Ibn Lādin and his associates had a lot to make up for, especially if they wanted to continue staying under the protection of the Tälibān in the AfghanistanPakistan Frontier region. After a period of rather self-confident and increasingly independent acting, it was time again to submit to the authority of the Afghan leader of the Tălibān, Mullā Muhammad 'Umar. ${ }^{50}$

47) See, for example, the account on camp life by an unidentified witness on the second day in the trial "United States of America v. Usama bin Laden, et al." [S(7) 98 Cr. 1023], 6 February 2001. In Daily Transcripts of the USA v. Usama bin Laden et al. Trial in the Southern District of New York. Digital Files from the Court Reporters Office (212) 805-0300. URL: http://cryptome.org/usa-v-ubl02.htm (accessed 25 August 2015).

48) See, e.g., Alan Cullison. 'Inside Al-Qaeda's Hard Drive.' The Atlantic Monthly 294: 2 (2004), 5570, here 58f; Rashid, Taliban, 139.

49) See 'Nașs bayān al-jabha al-islāmiyya al-'ālamiyya li-jihād al-yahūd wa'l-ṣālibiȳ̄n.' al-Quds al'arabì 2,732 (26 Shawwāl 1418/23 February 1998), 3.

50) As an interesting aside, it is worth comparing this to the words of Ibn Lādin's former companion and Egyptian al-Qāiida ideologue Sayyid Imām al-Sharīf, noms-de guerre "Dr Faḍll" and "Abd al-Qādir ibn 'Abd al-'Azīz” (b. 1369/1950), who interpreted Ibn Lādin's acting out of Afghanistan in contravention of explicit orders from Mullā 'Umar as a breach of the stipulation for asylum and hospitality (al-aqd al-amān). This, among other points of criticism, was used by Sayyid Imām in his Mudhakkirat al-táriyya li-kitāb al-tabri'a from 2008 as a tool to delegitimise the al-Q̄ácida organization. See Muḥammad Muṣțafá Abū Shāma. 'D. Faḍl munaẓẓir al-jihādiȳ̄n: kitāb al-Ẓawāhirī kadhb wa-buhtān wa-mughālițāt fiqhiyya wa-talbīs 'alá al-qāri': halqqa thāniyya.' al-Sharq al-awsat 10,949 (20 Dhī al-qa'da 1429/19 November 2008), URL: http://archive.aawsat.com/details.asp?section $=4 \&$ issueno $=10949 \&$ article $=495514 \&$ search $=\% 25 \mathrm{C} 7 \% 25 \mathrm{E} 1 \% 25 \mathrm{D} 9 \% 25 \mathrm{E} 6 \% 25 \mathrm{C} 7 \% 25 \mathrm{E} 5 \% 25 \mathrm{D}$ 1\%25ED\&state $=$ true/details.asp\#.VhK6vpdz8yl (accessed 5 October 2015). Similar criticisms have also been put forth by Muștafá Aḥmad Muḥammad 'Uthmān Abū al-Yazīd, nom-de-guerre "Sa'īd al-Mișrî̀" (killed 1431/2010), yet another of Ibn Lādin’s former Egyptian confidants, at around the very same time. See Muḥammad Shāfi '̄i. "Aqala «al-Qā'ida» ... al-ḥisābī.' al-Sharq al-awsat 10,860 (19 Sha'bān 1429/22 August 2008), URL: http://archive. aawsat.com/details.asp? section $=45 \&$ issueno $=10860 \&$ article $=483754 \&$ search $=\% 25 \mathrm{CF} . \% 2520 \% 25 \mathrm{DD} \% 25 \mathrm{D} 6 \% 25 \mathrm{E} 1 \&$ sta te=true/details.asp\#.VhK7U5dz8y2 (accessed 5 October 2015). 
Oddly however, already a few months earlier, in mid-June 2001, Ibn Lādin emphatically reaffirmed his pledge of allegiance to Mullā 'Umar, stating - with reference to Prophetic hadith, the precedence of the consensus of the sahäba and even the legal opinion of Muhammad ibn 'Abd al-Wahhāb (d. 1206/1791) on the issue - that this pledge would constituted a "supreme one" (bay'a 'uzmá) and its validity therefore was not confined to a limited time span. ${ }^{51}$ Only a few months later, about a fortnight after 9/11, Ibn Lādin stated in his First Address to the People of Pakistan:

I decree that you, oh brethren from among those who are firm on the walk of jih $\bar{a} d$ in the Path of God [and] in emulation of the Prophet - God's blessing upon him and peace - [are now joined] with the heroic and faithful Afghan people under the leadership of our commander of the mujähidīn, invigorated by his religion, the Commander of the Faithful Mullā Muhammad 'Umar. ${ }^{52}$

On the basis of the retrospective account of Ibn Lādin's one-time retainer Muștafá Hāmid, nom-de-guerre "Abū Walīd al-Miṣrī” (b. 1364/1945), however, Vahid Brown argues convincingly that Ibn Lādin's bay'a to Mullā 'Umar was hardly without ambiguity, ${ }^{53}$ concluding that this 'challenges the notion that al-Qa'ida is, or ever was, subservient to the aims and method of the Afghan Taliban. On the contrary, this purported subservience is a useful illusion that obscures al-Qa ida's fundamental conflicts with the Afghan Taliban agenda. ${ }^{54}$ Pledging allegiance was thus first and foremost a strategic tool for pursuing one's own interests. In fact, as Muștafá Hāmid points out, 'Abū 'Abdallāh [Ibn Lādin] continued to disobey the basic rules [al-ta'timmāt al-asāsiyya] of the Commander of the Faithful', ${ }^{55}$ one of which was to refrain at all cost from all militant action against American targets.

The fact that the matter of Ibn Lādin's bay'a to Mullā 'Umar is currently hotly debated in militant Muslim circles, along with the fact that the video in which Ibn Lādin confirmed to have pledged the bay'a 'uzmá to the Afghan leader was not released by the media department of al-Q⿱㇒冋a' $i d a$ until July 2014, ties the matter to the current dispute over the legitimacy of Abū Bakr al-Baghdādī's claim of the caliphate. The discussion in Arab circles, however, revolves around the question of whether Ibn Lādin's bay'a to Mullā 'Umar expressed an acknowledgement of the Afghan leader as caliph, or only to a supreme military commander over a con-

51) See Ibn Lādin, 'Bushrayāt' (Mu'assasat al-saḥāb 13 July 2014), URL: www.youtube.com/ watch?v=UEqG H_t9x7Q (accessed 25 August 2015), mins. 36'09"'-38'39”. Also, see Cole Bunzel. From Paper State to Caliphate: The Ideology of the Islamic State (Washington, DC: Centre for Middle East Policy at Brookings 2015), 33; and Wagemakers, 'The Concept of bay' $a$ in the Islamic State's Ideology.' Perspectives on Terrorism 9:4 (2015), 98-106, here 102.

52) Ibn Lādin, al-Arshīf al-jāmic li-kalimāt wa-khițābāt imām al-mujāhidīn Usāma ibn Muhammad ibn Lādin — ḥafiẓahu allāh (n.p.: Shabakat al-burāq al-islāmiyya 1427/2006), 2.

53) See Hāmid, al-Sā’irūn niyāman (n.p. n.d.), $18-31$ (Qișsat al-bay'a al-'arabiyya li-'amīr al-mu’minīn "Mullā Muhammad 'Umar"), esp. 23-30; Vahid Brown. 'The Facade of Allegiance: Bin Ladin's Dubious Pledge to Mullah Omar.' CTC Sentinel 3:1 (2010), 1-6.

54) Ibid., $5 \mathrm{f}$.

55) Hāmid, Sāìūn, 30. 
fined territory. The latter view had initially been adopted by al-Zawāhirī while Ibn Lādin was still alive, stating that Mullā 'Umar was supreme Commander (amīr) over the Emirate of Afghanistan; allegiance to him was thus one of a soldier (jund $\vec{\imath}$ ) to those above him in the chain of command. ${ }^{56}$ This view, however, changed drastically in the light of Baghdādī's contested aspiration to the caliphate, and Zawāhirī would now, like Ibn Lādin before him, see good strategic value behind an acknowledgement of Mullā 'Umar as supreme leader.

All in all, then, in the heated controversy over the legitimacy of the caliphal claims of al-Baghdādī vis-à-vis Mullā 'Umar, the crucial question for the Arab participants with regard to the latter was, and still is, to ascertain whether or not the assumption of the epithet "amìr al-mu'minin" was a conscious, yet tacit claim to caliphate by the Afghan leader. Subordinate to this is the question of whether Usāma ibn Lādin's ostensible bay'a 'uzmá was, as earlier authors on this matter have established, ${ }^{57}$ indeed an acknowledgment of Mullā 'Umar as supreme leader of the entire Muslim umma, or whether Ibn Lādin had only declared his allegiance as to a military commander. Quite different, meanwhile, is the approach of current Afghan authors, such as aforementioned Abū 'Ușmān Sālārzạy, to whom we shall now turn.

\section{A T⿱älib Addresses the Current Situation}

The trigger for Sālārzay's elaborate response was once again one of regional significance. In January 2015, a faction of TTP activists under the leadership of Hāfiz Sa'īd Khān of the Orakzạy tribe and 'Abd al-Ra'ūf Khādim Abū Ṭalha — both killed in action soon afterwards - defected and pledged their readily-accepted allegiance to Abū Bakr al-Baghdādī. ${ }^{58}$ In turn, they were given a due place on the

\footnotetext{
56) See al-Ẓawāhirī, 'Liqā' al-maftūḥ ma'a al-duktūr Ayman al-Ẓawāhir̄̄ - al-ḥalaqa al-thāniyya' (Mu'assasat al-sahāab April 2008), URL: http://ia700400.us.archive.org/24/items/ ayman_zawhri/ leqa2_2.mp3 (accessed 25 August 2015), mins. 125'37' -126'00".

57) The question of a difference in quality of a bay' $a$, that is, the distinction between a "supreme" and a "lesser" one, appears to have occurred only long after the abolition of the Ottoman-held Caliphate in 1924. This is indicated by the fact that in Muhammad Rashīd Riḍā's (d. 1354/1935) popular systematic treatise on that matter, written only two years before the termination of the caliphate, the distinction between a "bay'a 'uẓmá" and a "bay'a sughrá" does not appear at all, even though the institution is portrayed here as already seriously undermined by constitutional elements. See al-Shaykh Muhammad Rashīd Riḍā. al-Khilāfa (Cairo: al-Zahrā' li'l-i'lām al-'arabī 1408/1988), 32-5 and 155-7. See also Ella Landau-Tasseron. The Religious Foundations of Political Allegiance: A Study of Bay'a in Pre-Modern Islam (Washington, DC: Hudson Institute 2010). The synonymy of "khilāfa" and "imāma 'użmá", which had been established much earlier (see, for example, Imām al-ḥaramayn Abū Ma'ālī al-Juwaynī. Ghiyāth al-umam fi'l-tiyāth al-zulam, ed. Dr Mușțafá Hilmī and Dr Fu'ād 'Abd al-Mun'im [Alexandria: Dār al-da'wa 1979] 68) and formed part of the title of Rashīd Riḍā's treatise, seems to have fostered the eventual terminological pairing with "bay'a 'uzmá".

58) See al-Shāmī. 'Qul: mūtū bi-ghayẓikum!' (Mu'assasat al-furqān li’-intājj al-ì lāmī 26 January 2015), URL: www.youtube.com/watch?v=pq61kGOa8AQ (accessed 2 July 2015), mins. 3’42”'$5^{\prime} 07^{\prime \prime}$.
} 
cognitive map ${ }^{59}$ of the $I S$ caliphate, on which the Persianate region that comprises of the Fārsī-speaking parts of Iran, Muslim Central Asia, Afghanistan and Pakistan including Kashmir constitutes the "Governorate Khurasan" (wilāyat Khurāsān). ${ }^{60}$ Being given command over their ancestral homelands as part of a geographically much larger political entity, the decisions of the so-called "shürá for Khurasan" are based on a normative framework devised in the culturally distinct region of Iraq and the Levant, which in turn does not recognize cultural specifics in the Pashtun areas as the Tälibān do.

Such a sensitivity to cultural specifics is also widely absent in the statements of such sworn Arab opponents to the $I S$ as Abū Muhammad al-Maqdisī and Abū Qatāda. The universalizing Salafist emphasis on 'aquida and manhaj in the light of the "Pious Elders" (al-șalaf al-sālih) as the two main constituents of their religious worldview is not automatically compatible with the more localized Deobandderived Hanafi heritage of the Tälibān. Therefore, while certainly recognizing the $I S$ as common adversary, ${ }^{61}$ critics like the above introduced Abū 'Ușmān Sālārzạy had to develop a largely alternative strategy in refuting the claims of the $I S$ in what, for the Tălibann, is perceived to be a regionally confined affair, in order to prevent further dissent within their ranks.

In doing so, the author introduces himself clearly as a representative of the new generation of Tälibān which has somewhat outgrown their intellectual dependency on the Deobandī scholarship that, especially with the Famiah-yi haqqāniyyah in Akorah Khattak near Peshawar, possesses a mighty presence in the Pashtun-dominated region of Pakistan. ${ }^{62}$ The generation of TTP activists like Sālārzạy, however, has increasingly turned against the less militant Deobandī

59) The concept of "cognitive maps", or "mental maps", has been established in Cultural Studies to generally frame any kind of spatial separation, cognitive spatial imaginaries, conceptual worlds, maps of significations, internal and external representations of concrete places and hierarchies of spatial values. See, for example, Roger M. Downs and David Stea. Maps in Mind: Reflections on Cognitive Mapping (New York: Harper \& Row 1977); Denis Cosgrove. 'Introduction: Mapping Meaning.' Mappings, ed. idem (London: Reaktion [sic] Books 1999), 1-23, esp. 9-16; Frithjof Benjamin Schenk. 'Mental Maps: Die Konstruktion von geographischen Räumen in Europa seit der Aufklärung.' Geschichte und Gesellschaft 29:3 (2002), 493-514. Lately, the term "significant geographies" has been introduced in this regard, to also capture literatures as representatives of mental maps.

60) For the $I S$ cognitive map, comprising by late September 2015 twenty-four wilāyāt, fifteen of which are sub-governorates of the Governorate of Iraq and the Levant, see https://dump.to/ Welayat or also the section containing reports from the governorates (al-makātib al-i lammiyya li'l-wilāyatt) on the official IS site https://isdarat.tv/ (both accessed 20 August 2015).

61) See al-Sālārza'̄î, Mawqif, 13 and 36, where he explicitly mentions al-Maqdis̄̄ and Abū Qatāda as 'of the scholars of the Salafi-Jihādī orientation' and their refutation of al-Baghdādī's caliphate on the ground of his erroneous manhaj that allows for the killing of fellow Muslims.

62) On the Fāmi'ah-yi haqqāniyyah, established right after the Partition in 1947, and its relationship to the Dār al-'ulūm at Deoband, see Jan-Peter Hartung. 'The Ṭālibān Legal Discourse on Violence.' Legitimate and Illegitimate Violence in Modern Islamic Thought, vol. 3, ed. Robert Gleave and Mustafa Baig (Edinburgh: EUP forthcoming). The relationship is also well indicated by the correspondence exchanged between the leadership of both institutions; see Mawlānā Samī̄ al-Haqq. Mashāhir ba-nām-i Mawlānā 'Abd al-Haqq va Mawlānā Samī al-Haqq, 7 vols. (Akorah Khațak: Mu'tamar al-muṣannifinn 1433/2012), I: 58-60, 86-91, 176-80, 326-52 and 576-85, IV: 259-63, and V: 281-4. 
culture of religious learning. Seasoned by their participation in combat "in the Path of God" and exposed to alternative explanatory frameworks through their interaction with non-Afghan militants operating in the Afghanistan-Pakistan borderlands, these upcoming cadres have embraced certain aspects of transnational Salafist thought that turned out to clash with distinct features of the Deobandi approach. The most obvious one appears to be the abandoning of the taqlìd shakhsin, that is, the ineluctable emulation of legal opinion of one's respective teaching authority 'in times of affliction and chaos [fitna va fasadd]' 63 which is usually bolstered by Sufi relationships of master and adept (piri-murid $\vec{\imath}$ ), and its emphatic replacement by an ijtihād that is oriented by precedence purportedly established by the salaf șälih.

Against the backdrop of the recent defection of the TTP contingent to the IS, the subsequent establishment of its "Khurasan shüra", and the resulting fear for further fragmentation of the Tâlibān movement, Sālārzạy sets out to deconstruct al-Baghdādī's caliphate as void. Interestingly, he does not do this by attempting to legitimize a caliphate held by Mullā 'Umar instead, but rather by presenting historical and legal arguments against al-Baghdādī alone. From this, the thrust of his argument appears clear: if al-Baghdādī's caliphate is not legitimate, then pledging allegiance to him is illegitimate, too; for the TTP defectors this implies in turn that their pledge of allegiance to Mullā 'Umar still holds value. Such an aspiration does not require a justification of Mullā 'Umar as "Commander of the Faithful", only the proof that al-Baghdādī's claims are not valid.

In the following, Sālārzạy's detailed argument shall briefly be sketched, in order to get a better sense of how distinct the mode of argumentation used by the Tälibān is from that of the Arabs. Instead, and without making an explicit point of it, Sālārzạy embraces a Salafist manhaj in his reasoning insofar as he provides a vast array or references, both classical and more contemporary, ranging from authors of the Arab world to South Asian ones. Moreover, his references to legal views embrace all four canonical traditions of fiqh. This way, Sālārzạy is able to present his readership with something approximating a consensus of the learned ones of the entire Muslim umma, past and present.

For kickoff, Sālārzay reiterates the four core points of the official statement of the Supreme Council of the TTP where they established their position towards al-Baghdādī's claims. First, the Council decreed, al-Baghdādī is leading a resistance 'against the coalition of crusaders, Zionists and deserters' ${ }^{64}$, but, counters

63) Haẓrat Mawlānā al-Hāj]j al-Hāfiz Rashīd Ạ̣mad Gangohī. Fatāvá-yi rashīdiyyah. mubavvab bi-țarz-i jadīd (Delhi: Dars̄i kutubkhānah 1987), 235. More extensively on taqlīd shakhșī, see also Shaykh al-Hind Mawlānā Mạ̣mūd al-Ḥasan Șāḥib-i Deobandī. Adillah-yi kāmilah, ya'n̄̄ ghayr-muqallidon ke das su'ālāt awr unke taḥqūì̄ javābāt (Karachi: Qadīmī kitābkhānah 1990), 73-88.

64) al-Sālārza'̄, Mawqif, 6. The term "deserters" (rawāfid) here serves as polemical appellation of the Shiites, as it is well established in Sunnite heresiographical traditions, most prominently here in the writings of Ibn Taymiyya (e.g. his Majmū̌at al-fatāwá, ed. 'Āmir al-Jazzār and Anwar al-Bāz, 37 vols. [al-Manșūra: Dār al-wafā' li’l-țaba'a wa'l-nashr ${ }^{21998], ~ I I I: ~ 221 ; ~ o r ~ t h e ~ M i n h a ̄ j ~ a l-s u n n a ~}$ al-nabawiyya fì naqd kalām al-shî́a al-qadariyya, ed. Dr. Muhammad Rashād Sālim, 9 vols. [Riyadh: Jāmi'at al-Imām Muhammad ibn Sa'ūd 1406/1986]). However, the context in which Sālārzạy uses this term suggests an alternative reading, as it could well refer to those who have deserted the 
Sālārzay, he is not the caliph of all Muslims, hence the traditionist argument that those who die without having pledged the bay' $a$ to a caliph would "die the death of the jähiliyya" does not apply to this context. ${ }^{65}$ Second, he states that the TTP's application of relevant Prophetic traditions in support of the case of al-Baghdādi distorts the meaning of these ahädith. Third, denouncing the manner in which the claimant requires the bay' $a$ from all those in the subjugated areas as part of their Sunnī creed, Sālārzay decries this as entirely unprecedented in the practice of the Companions and the Rightly-Guided Caliphs, and thus constituting an illegitimate innovation $\left(b i d^{k} a\right)$. Finally, and somewhat related to the previous allegation, he declares that the introduction of a new form of caliphate runs counter to the Qur'ānic notion that Islam is a complete and perfect religion. ${ }^{66}$

Over the following pages, Sālārzạy provides an extensive commentary to these four points, thus adding substance to the claim that all four points have been derived according to the $\operatorname{shari}^{-1} a$, that is to say in light of the Qur'ann, the Prophetic Sunna and the consensus of the umma. His exposition has been split into twenty-two points of varying length. These do not aim at establishing Mullā 'Umar as the rightful caliph against al-Baghdādī, but rather to provide a sound argument for why the defection of a small band of former Tälibān neither legitimises al-Baghdādī's claims to the, nor constitutes any reason for the Tialibān as a whole to submit themselves to the $I S$ and its trans-territorial agenda. If some Tălibān felt like pledging their allegiance to al-Baghdādī there was little that could be done about it. If, however, they wanted to compel others to follow their example, then the questionable character of al-Baghdādī's caliphal claims needed to be exposed in the light of the Qur'ān, the Prophetic Sunna, and an as large as possible consensus of the scholarly community.

This appears exactly to be what Sālārzạy is aiming for. His arguments refer, among others, to the procedure in which al-Baghdādî's caliphate was purportedly established, the qualification of those who appointed him and affirmed him in this position, to the purpose that it serves for al-Baghdādī personally, and the limited territorial validity of his caliphate. ${ }^{67}$ In order to lend more substance to his deliberations, Sālārzạy quotes extensively from an abundance of classical as well as more contemporary reference works, ${ }^{68}$ even though a thorough cross-check re-

Imam to whom they have initially pledged their allegiance. Hence, the term could have deliberately been employed to refer to the members of the "Khurasan shürá".

65) The reference here is to Muslim, Saḥ̄h, kitāb al-imāra, bāb al-amr bi-luzūm al-jamā'a 'inda zuhūr al-fitan wa-taḥdhīr al-du'āt ilá al-kufr, hadīth 10 (no. 4,686).

66) The Qur'ānic reference here is 5 (al-Mā'ida): 3: 'Today I have perfected for you your dīn.'

67) This is more or less the extent of the first five reasons for why al-Baghdādī's caliphate is to be considered only a feigned one (maz'ūma). See al-Sālārza'̄̄, Mawqif, 7-33.

68) For backup on the first point, that al-Baghdādī's appointment did not correspond with the three established modes of caliphal succession by a consensus (see ibid., 7-10), Sālārzạy referred to Ibn Khaldūn's historico-typological exposition, as well as the critical evaluations of Ibn Taymiyya and the medieval Shāfi ite jurist Yahyá ibn Ab̄̄ Khayr al-'Umrān̄̄ of the contested caliphate of 'Alī ibn Abī Ṭālib. compare Walī al-Dīn 'Abd al-Raḥmān ibn Muhammad ibn Khaldūn. Muqaddimat Ibn Khaldūn. Edited by 'Abdallāh Muhạmmad Darw̄ish, 2 vols. (Damascus: Dār ya'rrib li'l-dirāsāt wa'l-nashr wa'l-tawzī' 1425/2004), I: 391-9, esp. 395; Ibn Taymiyya, Shubuhāt hawla al-ṣahāba 
veals that the cited passages all belong to rather confined and contiguous sections of voluminous works, and, moreover, have been cited repeatedly across the whole treatise. A prominent example here are the works of Ibn Taymiyya, first and foremost his seminal Minhāj al-sunna al-nabawiyya, which suggests that Sālārzạy assigned him a key role in his various arguments. ${ }^{69}$

Such frequent recourse to Ibn Taymiyya is to be regarded as a clever move: after all, the medieval Damascene traditionist figures among the chief references for Salafists. Moreover, the title of this work in particular gives a clear and useful indication that Sālārzạy considers his opponents to be in violation of Prophetic precedent. It is therefore not surprising that this constitutes Sālārzạy's main reference in this regard, though it is certainly not his only argument. Rather, he also refers to classical authors from all four canonical madhāhib al-fiqh: for the Shāficites, for example, he refers to Abū 'l-Hasan al-Māwardī (d. 450/1058), Abū Hāmid al-Ghazālī (d. 555/1111), Yahyyá ibn Abī Khayr al-'Umrānī (d. 558/1163), Badr al-Dīn ibn Jamā'a (d. 733/1333), Shams al-Dīn al-Dhahabī (d. 748/1348) and Abū 'l-Fidā' Ismā̄îl ibn Kathīr (d. 774/1373), Jalāl al-Dīn al-Suyūṭi (d. 911/1505) and Shams al-Dīn al-Ramlī (d. 1004/1596). ${ }^{70}$ A similar array of reference works Sālārzạy provides also for the Hanafites, ${ }^{71}$ the Mālikites ${ }^{72}$ and the Hanbalites. ${ }^{73}$

wa'l-radd 'alayhā, ed. Muhammad Mālallāh, 2 vols. (Cairo: Maktabat Ibn Taymiyya 1410/1989), II: 11; Yahyyá ibn Abī 'l-Khayr al-'Umrānī. al-Intișār fi'l-radd 'alá al-mu'tazila al-qadariyya, ed. Dr. Sa'ūd ibn 'Abd al-'Azīz al-Khalaf (Medina: al-Jāmi'a al-islāmiyya 1419h), 900.

69) Across Sālārzạy's treatise there are fourteen reference to the Minhāj al-sunna. See al-Sālārza'̄i Mawqif, 11-13, 20, 30, 34-6 and 56. These references, however, are drawn from a rather limited selection of passages from Ibn Taymiyya's work and, on occasion, misquoted. Compare Ibn Taymiyya, Minhäj, I: 526f, 530, 532f and III: 386.

70) See ibid., 10, 13, 15f, 20, 22, 26, 30, 33, 35, 37, 42-4, 46, 51, 53 and 55. Compare Abū 'l-Hasan 'Alī al-Mawārdī. Tashīl al-nazar wa-ta'jūl al-zafar fì akhlāq al-malik wa-siyāsa lìl-mulk, ed. Muhȳ̄ Hilāl al-Sarḥān (Beirut: Dār al-nahḍa al-'arabiyya 1981), 168 and 258; idem, Kitāb al-ahkām al-sulțāniyya wa'l-wilāyāt al-dīniyya, ed. Dr. Aḥmad Mubārak al-Baghdād̄̄ (Kuwait: Dār Ibn Qutayba 1409/1989), 22f; Abū Hāmid Muḥammad al-Ghazālī. Faḍ̄’ḥ al-bātiniyya, ed. 'Abd al-Rahmmān Badawī (Kuwait: Mu'assasat dār al-kutub al-thaqāfiyya 1383/1964); 177; al-'Umrānī, al-Intișār, 836 and 900; Badr al-Dīn Ibn Jamā'a. Tahrīr al-ahkām fì tadbīr al-islām, ed. Dr Fu'ād 'Abd al-Mun'im Aḥmad (Doha: Ri'āsat al-maḥākim al-shar'iyya wa'l-shu’ūn al-dīniyya 1405/1985), 65; al-Ḥāiz Abū 'Abdallāh Muhammad ibn 'Uthmān al-Dhahabī. Muntaqá min minhāj al-ítidāl fì naqd kalām ahl al-rafḍ wa'l-ítizāl, wa-huwa mukhtașar minhāj al-sunna, ed. Muhibb al-Dīn al-Khatīb (Riyadh: al-Ri'āsa al-'āmma li-'idārāt al-buhūth al-'ilmiyya wa'l-iftā' wa'l-da'wa wa'l-irshād ${ }^{3} 1413 \mathrm{~h}$ ), 62; al-Ḥāfiz 'Imād al-Dīn ibn Kathīr. al-Bidāya wa'l-nihāya, ed. Dr. 'Abdallāh ibn 'Abd al-Muhsin al-Turkī, 21 vols. (Giza et al.: Dār Hajar 1417/1997), X: 220f; Muhammad ibn Jar̄̄r al-Ṭabarī. Ta'rīkh al-Ṭabari: ta'rīkh al-umam wa'l-mulūk, ed. Nawāf al-Jarrāḥ, 6 vols. (Beirut: Dār Ṣādir ${ }^{2}$ 1426/2005), II: 751; al-Imām al-Hāfiz Jalāl al-Dīn al-Suyūṭi. Ta'rīkh al-khulafầ, ed. Markaz al-minhāj li'l-dirāsāt wa'l-taḥqīq al-'ilm̄̄ (Jeddah et al.: Dār al-minhāj 21434/2013), 87f; Shams al-Dīn Muhạmmad al-Ramlī. Nihāyat al-muhtāj ilá sharh al-minhāj fíl-fiqh 'alá madhhab al-Imām al-Shāfì — radiy allāhu 'anhu, ed. Muhạmmad 'Alī Bayḍūn, 8 vols. (Beirut: Dār al-kutub al-ilmiyya $\left.{ }^{3} 1424 / 2003\right)$, VII: 410.

71) Sālārzạy's Hanafite reference authors include Zayn al-Dīn ibn Nujaym (d. 97 1/1563) and 'Alā al-Dīn al-Haṣkafì (d. 1088/1677), who both endorsed the earlier Hasan ibn Manṣūr "Qāḍi Khān" of Farghana (d. 592/1196). See al-Sālārza'̄̄, Mawqif, 26f, 29f and 49f; compare Muhammad ibn 'Alī al-Haṣkafì. al-Durr al-mukhtār sharh tanwīr al-abșār wa-jāmi' al-bahār, ed. 'Abd al-Mun'im Khalīl Ibrāhīm (Beirut: Dār al-kutub al-'ilmiyya 1423/2002), 351; Zayn al-Dīn ibn Nujaym. Bahrr al-rā’iq 
Besides such references to classical legal works, he also refers on occasion to mainstream Sunnite theological works, mainly of Ash'arite and Māturīdite background, ${ }^{74}$ spiked with the common references to Ibn Taymiyya's theology as a more traditionist perspective. This way, Sālārzạy appears to have covered much of the legal and theological tradition, without showing clear signs of a Hanafite persuasion such that a Deobandī would stand for. By doing so, and without assigning his references to particular scholarly traditions, Sālārzạy suggests a robust consensus among the learned of the past in matters such as the number and qualifications of the ahl al-hall wa'l-'aqd - those entitled to assert or deny a caliphate - across the divides of different legal and theological traditions.

On the other hand, there are certain aspects in al-Baghdādī's case which cannot be best addressed with recourse to the classical Islamic tradition. After all, the formal abolition of the Ottoman-held caliphate (who, in turn, claimed to hold it in succession to the Abbasids) in 1924 created a new reality that strongly impacted the further development of a caliphate-centred political theory. It is therefore not really surprising that Sālārzạy needed to also include such later deliberations, which seem to have started prominently with Muhammad Rashīd Riḍā's (d. 1354/1935) treatise al-Khilāfa aw al-imāma al-'uzmá, ${ }^{75}$ a text which holds a corresponding prominence in Sālārzạy's more contemporary references. ${ }^{76}$ Alt-

'alá sharh kanz al-daqā’iq, ed. Zakariyā 'Umayrāt, 9 vols. (Beirut: Dār al-kutub al-ilmiyya 1418/1997), VI: 439. The two quotes, ostensibly taken from Qāḍi Khān, are in fact taken from the two later authors. Compare Fakhr al-Dīn Qāḍī Khān. Fatāwá Qaụikhān fì madhhab al-imām al-ązam Abì Hañ̄fa al-Númān, ed. Sālim Mușțafá al-Badarī, 3 vols. (Beirut: Dār al-kutub al-ilmiyya 2009).

72) Sālārzạy's Mālikite reference authors comprise of Abū Barakāt Aḥmad al-Dardīr (d. 1201/1786) and Muḥammad ibn Aḥmad ibn 'Arafa al-Dasūqī (d. 1230/1815), who have both commented on the «Muwața'»» of Mālik ibn Anas (d. 179/711). See al-Sālārza’̄̄, Mawqif, 32; compare Abū Barakāt Aḥmad al-Ṣāwī. Hāashiya 'alá sharh șaghīr 'alá al-masālik ilá madhhab al-Imām Mālik, ed. Dr. Mușțafá Kamāl Wașafī, 4 vols. (Cairo: Dār al-ma'ārif 1986), IV: 427; 'Allāma Shams alDīn Shaykh Muhammad al-Dasūqī. Hāshivat al-Dasūqū 'alá sharh kabīr, 4 vols. (Cairo: Dār ihyā̄' al-kutub al-'arabiyya n.d. [reprint from ed. 1304h]), IV: 298.

73) Sālārzạy’s Hanbalite reference authors include, besides Ibn Taymiyya, also Qāọī Abū Ya lá al-Farrā' al-Hanbalī (d. 458/1065) and Aḥmad ibn Qudāma al-Maqdis̄ī (d. 620/1223). See al-Sālārza'̄̄, Mawqif, 31; compare al-Qāọ̄i Abū Ya lá Muhammad ibn al-Husayn al-Farrā'. al-Aḥkām al-sultāniyya, ed. Muḥammad Hāmid al-Fayq̄i (Beirut: Dār al-kutub al-ilmiyya 1421/2000), 23; Mu’affaq al-Dīn Abū Muhammad ibn Qudāma. al-Mughn̄̄, ed. 'Abdallāh ibn 'Abd al-Muḥsin al-Turkī and 'Abd al-Fattāḥ Muḥammad al-Hulw, 15 vols. (Riyadh: Dār 'ālam al-kutub ${ }^{3} 1417$ /1997), XIII: 17.

74) Chief references in this regard are the Ash'arite systematiser 'Adud al-Dīn al-İjī of Shiraz (d. 756/1355), who clearly argued against the Mu'tazilite-cum-Zaydite position on the matter, as well as his Māturidite counterpart Sa'd al-Dīn Taftāzānī (d. 792/1390) from Samarqand. See al-Sālārza'̄̄, Mawqif, 22, 24 and 29; compare 'Aḍudallāh wa'l-dīn al-Qāḍī 'Abd al-Raḥmān ibn Aḥmad al-İjī. al-Mawāqif fì 'ilm al-kalām (Beirut: 'Ālam al-kutub 1405/1984), 398-414; and Sa'd al-Dīn al-Taftazānī. Sharh al-maqāsid fì 'ilm al-kalām, ed. Șālị̣ Mūsá Sharaf, 5 vols. (Beirut: 'Ālam al-kutub 21419/1998), V: 232f and 255.

75) It appears likely that Riḍa had initially planned to publish this work in a serialized form on his propaganda platform al-Manār. However, only its introduction had been published here. See Riḍā, 'Fātiḥat kitāb al-Khilāfa — aw al-imāma al-'uẓmá.' al-Manār 24:6 (1341/1923), 359-66.

76) See al-Sālārza'̄i, Mawqif, 25 and 29. 
hough all his cited works are interspersed without contextualization from case to case, they can nonetheless be classed into a few distinct groups. The most prominent appears to be relevant texts from Islamist authors: the spectrum ranges here from Abū 'l-A'lá Mawdūdī (d. 1979) and his distinct ideas of "khilāfa" to the

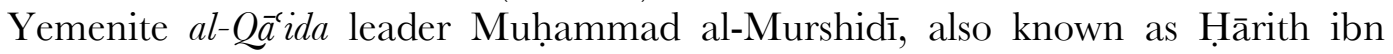
Ghāzī al-Nazāāì (killed 1436/2015), including such illustrious figures like the controversial Muḥammad 'Amāra (b. 1350/1931) from Egypt, Șalāḥ al-Ṣāwī (b. 1374/1954), also an Egyptian and ardent admirer of Sayyid Quṭb, who is currently Secretary General of the Sacramento-based Assembly of Muslim Furists of America, as well as also the Libyan Muhammad 'Alì Șallābī (b. 1963) from Benghazi, founder of the Hizb al-Watan. ${ }^{77}$ The inclusion of Taqī al-Dīn al-Nabhānī (d. 1397/1977) seems especially significant here, because the Hizb al-Tahrir (HuT) founder and his ideas do not generally appear to play any role at all in the current debates over the caliphate outside HuT circles. $^{78}$

This group of Islamist reference points is complemented by authors from within the wider Tâlibān circles: here feature the influential muftì Rashīd Ahmad Ludhiyānavī (d. 1422/2002), the former Minister of Information of the Islamic Emirate 'Abd al-Bāqī Haqqān̄i, and remarkably also the luminous 'Abd al-Rahīm Muslim Dost (b. 1380/1960), ${ }^{79}$ who has meanwhile, on 2 July 2014, declared his allegiance to Abū Bakr al-Baghdādī and the $I S$ and has allegedly been elevated to amīr of the Wilāyat Khürāsān only recently. ${ }^{80}$

Both these more politically motivated groups of authors are supplemented by a number of jurists and scholars of hadith. Especially significant in this regard appears the frequent recourse to more encyclopaedic works on fiqh that present a systematic and balanced treatment of the issues at hand, taking into consideration contemporary developments in Islamic jurisprudence. Outstanding in this regard appear al-Fiqh al-islämi wa-adillatuhu by the Syrian professor of $\operatorname{sharĩ}^{-i}$ law at the University of Damascus Wahba Muștafá al-Zuhaylī (d. 1436/2015) and the most extensive Mawsū' a al-fiqhiyya al-kuwaytiyya, issued by the Government of Kuwait. ${ }^{81}$

77) See ibid., 8, 16, 23, 35 and 52; compare Sayyid Abū 'l-A'lá Mawdūdī. Khilāfat va mulukiyyat (Delhi: Markazī maktaba-yi islāmī 1997), 123-31; Dr. Șalāḥ al-Ṣāwī. al-Waj̄̄z fì fiqh al-khilāfa (Cairo: Dār i'lām al-duwalī 2008), 49; Dr. Muhammad 'Amāra. al-Islām wa-falsafat al-hukm (Beirut: Dār al-shurūq 1409/1989), 250-4; al-Ṣallābī (1427/2006), 66; Hārith ibn Ghāzī al-Naz̄ārī. Aḥkām al-imāra (n.p.: Mu'assasat al-malāhim al-tuqaddim 1435/2014), 14-20. The latter is based on the second of a series of nine lectures, initially published by the Media Department of al-Q $\bar{a}$ c $i d a$ in Yemen, the Mu'assasat al-malähim al-taqaddum. On the concept of khiläfa in the systematic thought of Mawdūdī, see Hartung. A System of Life: Mawdūdī and the Ideologisation of Islam (London: Hurst/New York: OUP 2013), 103-22.

78) See al-Sālārza'̄̄, Mawqif, 39 and 47f; compare Taq̄̄ al-Dīn al-Nabhān̄̄. al-Shakhṣiyya al-islāmiyya, 2 vols. (Beirut: Dār al-umma $\left.{ }^{6} 1422 / 2001\right)$, II: 151.

79) See al-Sālārza'̄i, Mawqif, 39.

80) See 'Bay'at al-shaykh 'Abd al-Rahīm Muslim Dost al-Afghānī — hafiẓahu allāh — li-khalīfat al-muslimīn wa-imāmihim Abū Bakr al-Baghdādī — hafiẓahu allāh', URL: https:// archive.org/details/doost (accessed 31 August 2015), mins. 10'04" to 19'41"'.

81) See al-Sālārza'̄̄, Mawqif, 14, 20, 26f, 34, 48f and 54; compare Dr. Wahba al-Zuhaylī. al-Fiqh al-islām̄̄ wa-adillatuhu: shāmil li'l-adilla al-shar'iyya wa'l-ärä' al-madhhabiyya wa-ahamm al-nazariyyāt alfiqhiyya wa-taḥq̄q al-ahādìth al-nabawiyya wa-tahrī̄ihā, 8 vols. (Damascus: Dār al-fikr ${ }^{2}$ 1405/1985), VI: 
All these diverse references from different times, different regions and even different intellectual persuasions serve to present Sālārzạy's points against the claims of caliphate by al-Baghdādī and his supporters as expression of a wide consensus of Muslim scholars past and present, radical and moderate. Finally, repeated emphasis on the issue of "territoriality" in relation to caliphate is crucial here: according to Sālārzạy, and backed up again with classical as well as more contemporary references, a caliphate requires a dār al-islām in which it resides and for which a caliph oversees the worldly and religious affairs (al-wilāya al-'ämma

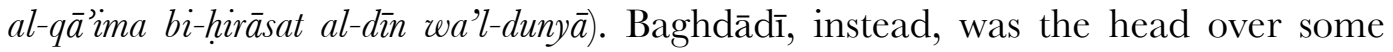
militant association (al-majmūa ât al-jihädiyya), to proclaim him caliph for the entire Muslim umma would thus amount to a rather questionable amity (tawallîे) of his followers. ${ }^{82}$ Therefore, al-Baghdādī right to rule is territorially confined, and his rules and regulations cannot legitimately be enforced in regions not under his control, such as Khurasan. ${ }^{83}$ This seems to be the crunch point of Sālārzạy's whole argument: The IS may set up a shürá for a "Governorate Khurasan" as it pleases, because this would not have any compelling bearings on the people in the region. If al-Baghdādī's retainers there were about to enforce obedience to the $I S$ then this would be entirely illegitimate from a shari $a$ point of view, and any such attempt could therefore be suppressed as criminal behaviour. In charge of such just and necessary suppression would, in turn, be those who maintain dominance in the territory and assert the older claims of religious, social and political authority, that is, the Täliban under its supreme commander. Who this commander actually is, however, appears of subordinate importance: this explains why Sālārzạy did not need to strike a blow for the person of Mulla Muhammad 'Umar and could easily apply his conclusion to Mullā 'Umar's eventual successor as supreme commander of the Tâalibān, Mullā Akhtar Manșūr.

\section{Conclusion}

The fierce debate over the legitimacy of the caliphate of Abū Bakr al-Baghdādi and, by implication, the entire $I S$, is certainly impacting militant Muslim circles worldwide. While the band of supporters appears to grow on a daily basis, there is still substantial rejection. The main carrier of the criticisms appears to be al-Q $\bar{a} i d a$, from which the $I S$ had ultimately grown. It surprises little therefore that, despite the mutual criticisms, the speakers for both organizations maintain a somewhat common agenda and a global vision.

686f and 692; Wizārat al-awqāf wa'l-shu'ūn al-islāmiyya (ed.). al-Mawsū̌ca al-fiqhiyya al-kuwaytiyya, 45 vols. (Kuwait: Wizārat al-awqāf wa'l-shu'ūn al-islāmiyya ${ }^{21404 / 1983), ~ V I: ~} 216$ and VII: 115.

82) See al-Sālārza'̄̄, Mawqif, 24f; compare Abū 'l-'Abbās Aḥmad al-Qalqashandī. Mā’thir al-ināfa fi'l-ma'ālim al-khilāfa, ed. 'Abd al-Sattār Aḥmad Farāj, 3 vols. (Beirut: 'Ālam al-kutub 2006), I: 8f; alSayyid Muḥammad 'Abd al-Hayy al-Kattān̄̄. Niz̄ām al-ḥukūma al-nabawiyya al-musammá al-tarātīb al-idariyya, ed. Dr. 'Abdallāh al-Khālid, 2 vols. (Beirut: Dār al-arqām n.d.), I: 79; al-Taftazānī, Maqāṣid, V: 232; Riḍā, al-Khilāfa, 17 (Sālārzạy paraphrases the respective passages here, rather than citing it verbatim).

83) See al-Sālārza'̄̄, Mawqif, 47f. 
However, not all of these militant Muslim circles that take part in the debate share this backdrop. The Tälibān, reeled into the discussion due to their own quite complicated relationship with $a l-Q \bar{a}^{c} i d a$ and the fact that the latter has increasingly attempted to present the supreme commander of the Tälibān, Mullā Muhammad "Umar, as a "counter caliph", 84 are one such group. The defection of some activists of the TTP, the Pakistani branch of the movement, to the IS in January 2015 and the subsequent establishment of a shürá for the "Governorate Khurasan", covering a vast area including Afghanistan and Pakistan, necessitated a fast and determined response. This came in an official statement by the Leadership Council of the TTP, followed instantly by the publication of Abū 'Ușmān Sālārzạy's treatise on that matter only four months after the defection took place. This author, however, about whom little information is available in the public domain, represents already a qualitative leap away from the original roots of the Tialibān movement in the Deobandī orientation of Indo-Muslim scholarship towards a more Salafist approach that does not take well the confines of a certain scholastic tradition. While a methodical approximation of those cohorts that form the backbone

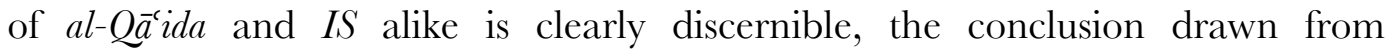
Sālārzạy's twenty-two points have a distinct regionalist colour, which reflects the strong sense of autonomy in Pashtun social and political tradition. This explains why Sālārzạy did not need to strike a blow for the person of Mullā Muhammad 'Umar and could easily apply his conclusion to Mullā Akhtar Manșūr as the latter's eventual successor as supreme commander of the Tälibān.

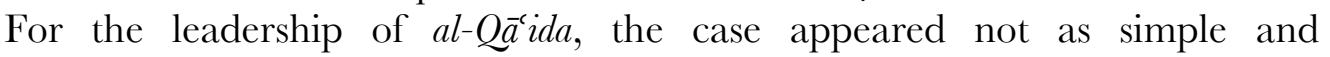
straightforward. Because their dispute with the $I S$ was not in the first place to retain their autonomous claim over a distinct region, but rather over the monopoly of definition in a perceived global jihâd, the refutation of al-Baghdādī needed to go hand in hand with the establishment of an alternative, and be it only as a formality with little intention to really submit to it. This is the background against which the $a l-Q \bar{a} i d a$ leadership decided on the public release of Ibn Lādin's acknowledgement of Mullā 'Umar as supreme Muslim leader from thirteen years earlier, and also on al-Zawāhirī's recent pledge of allegiance to Akhtar Manșūr. ${ }^{85}$

A refreshed view of this bay' $a$ is well suited to indicate the different discourses

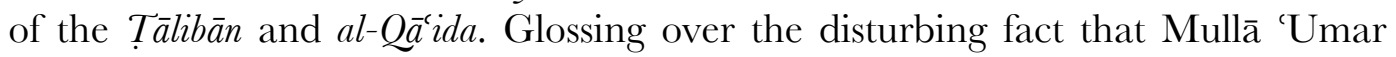
has purportedly died already in April 2013, yet had miraculously managed to convey his ' $\bar{I} d$ greetings for the following three years ${ }^{86}$ the text of al-Zawāhirì's bay'a,

84) See Bunzel, 'Al-Qaeda's Quasi-Caliph: The Recasting of Mulla 'Umar.' j̈hadica.com (2014). URL: $\quad$ www.jihadica.com/al-qaeda $\%$ E2 $\% 80 \% 99$ s-quasi-caliph-the-recasting-of-mullah$\%$ E2\%80\%98um ar/ (accessed 31 August 2015).

85) See al-Zawāhirī, al-Bay'a.

86) The text of Mullā 'Umar's 'Īd address for the year $1436(\sim 2015)$ remained live for about a fortnight on the official website of the Islamic Emirate of Afghanistan even after he had been declared dead on 30 July 2015. Meanwhile, however, it has been removed from the website in each of the five languages editions Arabic, Pashto, Dari, Urdu and English. His message for 'İd al-fițr 1434 (8 August 2013) had been published in various official journals of the Islamic Emirate of Afghanistan, which have meanwhile also all disappeared from the website, but are still available with the author of this article. See 'Bayān amīr al-mu'minīn — hafiẓahu allāh — bi-munāsibat 'īd 
again considered to be a bay'a 'uzmá, is somewhat revealing with regard to the more sinister global agenda of $a l-Q \bar{a}^{c} i d a$ :

And we pledge allegiance to you on the disavowal of every rule, system, placement, treaty, agreement or covenant [kull ḥukm aw nizām aw wadac aw 'ahd aw ittifāq aw mithāq] that contravenes the $\operatorname{sharî}^{-1} a$, whether a system is within the land of the Muslims, or outside of it. [...] And we pledge allegiance to you in the jih $\bar{a} d$ to liberate every span of land of the Muslims that has been usurped and violated, from Kashghar to al-Andalus, from the Caucasus to Somalia and Central Africa, from Kashmir to Jerusalem, from the Philippines to Kabul, Bukhara and Samarqand. ${ }^{87}$

While Mullā Akhtar Manșūr appears to have accepted this bay'a, ${ }^{88}$ the public statements of the Tälibān under his command nonetheless do not suggest a globally expanded agenda of the movement, as suggested by al-Zawāhirī. In a public statement to the Afghan Islamic Press (Afghān islämī ažanns) from 25 August 2015, Hājjjī Ismāî̀l Zabīịallāh Mujāhid (b. 1393/1973), one of the official spokesmen for the Islamic Emirate, indicated that while the sympathies of the Tâlibān certainly go out to all Muslim brethren and sisters worldwide, the agenda will still maintain its regional focus. Asked about the significance of al-Zawāhirī's bay'a, Zabīhallāh states that

We have not asked anyone from outside of our country to pledge their allegiance to us, but if they do so because of their own affection [to us (muhabbat)] then we have no religious grounds to reject their pledge. Rather, we must respond reciprocally to their affection. 89

Affection alone, however, is certainly not what the leadership of $a l-Q \bar{a}^{c} i d a$ is after. The imbalance of aspirations, coupled with the intricate entanglement of the Tälibān in a global Muslim militant discourse, will ensure that - at least for the time being - the Tälibān remain caught between a rock and a hard place.

al-fiṭr.' al-Sumūd 8:8 (1434/2013), 2-5; 'Amīr al-mu’minīn Mullā Muhammad 'Umar Mujāhid — hafiẓahu allāh — kā payghām.’ Sharīat 2:6 (1434/2013), 4-8.

87) al-Zawāhirī, al-Bay'a, mins. 5'50" to 6'33'.

88) See ZZabīhallāh Mujāhid.

89) Ibid. 